Research.

\title{
The effect of price, comfort, and trust upon the decision to buy at the online shop (Case study on the students at Economic College of Binaniaga)
}

\author{
Adri Wihananto \\ Department of Management, Universitas Binaniaga Indonesia, Bogor, Indonesia \\ adri.wihananto@gmail.com (A.Wihananto)
}

Received: March 20, 2020; Accepted: May 15, 2020; Published: June 30, 2020

To cite this article: Wihananto, Adri. 2020. The effect of price, comfort and trust upon the decision to buy at the online shop. (Case study on the students at Economic College of Binaniaga). The Management Journal of BINANIAGA. 5 (1): 01-10. doi: 10.33062/mjb.v5i01.369

\begin{abstract}
This research aims to find out the effects of the price, comfort, and trust simultaneously upon the decision to buy online, (Case study on the students of STIE Bina Niaga Bogor). Techniques of Analysis has applied multiple linear regression analysis to show the extent of which the price, comfort and trust either partially or simultaneously have affected the decision to buy online. Simultaneous result indicated that the effects of the price, comfort, trust either partially and simultaneously had affected the decision to buy online. This result is indicated by the value of $F_{\text {count }}$ of 40.938. However, $F_{\text {table }} d f: \alpha,(k-1),(n-k)=0.05,(2-1),(151-3)$ is 4.60 . Therefore the calculation of $F_{\text {count }}>F_{\text {table }}(40.938>4,60)$ at sig. value of $0.000<5 \%(0.05)$.
\end{abstract}

Keywords: Price, Confort, Trust, Decision to Buy Online.

\section{INTRODUCTION}

\section{Background}

The development of communication and information technology has been evolving so far offering unlimited worldwide business. Internet is not only limited to get information that is accessible in this media, but also it can be used as the facility to execute trading transaction with new market place and worldwide business networking which is unlimited time and place.

Recently, internet has been used as shopping media and online marketing of a product. Marketing media using internet or media social is more attractive for the people because its range is broader and larger than any other commercial network (Kotler and Amstrong, 2008:36).

The trend of online shopping has been starting to attract people, because the process of online purchase is not as complicated as offline purchase. Online purchase can minimize the time, cost and ease to purchase more rather than offline purchase as they have to visit the shop.

One factor that has been influencing someone make a decision to buy online is the price. Price is an important factor for the people because when they do online purchase, they can consider whether the cost spending is meeting their expectation about the product they purchase. In some cases, the price at online shop is cheaper than offline shop (Verina et al.: 2014). The research of Tjahjono, et al., (2013) indicated that the price had affected significantly the decision to buy online.

Instead of the price of online shopping, there is another variable which is affecting online transaction, it is online shopping comfortable. The customers have to feel safe and

Adri Wihananto. The effect of price, comfort and trust upon the decision to buy at the online shop. (Case study on the students at Economic College of Binaniaga) 
comfortable when they are going to perform online shopping, however, the sellers tasks are obliged to develop and keep the customers' trust (Palvia, 2009).

The customers trust is an important factor that can influence the customers to decide on buying online (Wijaya and Teguh, 2012:9). Only the customers who have trusted will do the transaction on internet media. The research of Mahkota (2014), indicated that trust factor had affected significantly the decision to buy using social networking websites. However, the result of Yursidar, et al., (2014) indicated that trust variable had not affected significantly the decision to buy online.

Referring to the background above, the writer is interested in describing furthermore about the research with the title of "The Effect of Price, Comfort and Trust upon The Decision to Buy at Online Shop (Case Study of the students of Economy Faculty STIE Binaniaga Bogor).

\section{Aims}

1. To figure out the effect of price partially upon the decision to use ojek (motorcycle service) online.

2. To figure out the effect of comfort partially upon the decision to use ojek (motorcycle service) online.

3. To figure out the effect of trust partially upon the decision to use online shop.

\section{LIBRARY REVIEW AND HYPOTHESES DEVELOPMENT}

\section{Price}

Price is a certain amount of money paid for a kind or product or service, or total of the value exchanged done by the customer to receive the benefit of having the product or service (Wijaya, 2014).

Meanwhile, price according to Morissan (2010:78) is related to what should have to be given by the consumer to buy a product or service which is usually using value of the money.

\section{Price Indicator}

1. Price or tariff which is relatively standard.

Price which is relatively standard has been the customers consideration to decide to use the product. Consumers are very selective about the price offered since there are so many competitors available. The more the price does not comply with the customer interest, the more the customers will go to another company, furthermore when the tariff offered does not comply with the standard given.

2. Price complies with the quality.

Customers will look for quality of the product, however, they will select which product complies with the price they can afford. As a matter of fact consumers know that there is a similar affordable product which is having almost the same quality with the branded one. Consumers are comparing among the same type of products.

c. Promo program or abodemen discount

Discount is reduced fare. Discount is prepared to get customers participation to make a decision to use the service (Tjiptono. (2015).

\section{Comfort}

According to Palvia (2009). Online purchase comfort is occured when customers are comfortable when they execute the online transaction. Along with the opinion

Adri Wihananto. The effect of price, comfort and trust upon the decision to buy at the online shop.

(Case study on the students at Economic College of Binaniaga)

Page : 2 
aforementioned, Sarkar (2011) mentioned that customers who enjoy online shopping will move from conventional shopping to online shopping.

\section{Trust}

Trust is defined as customers who believe that e-vendor is having ethical behavior. Trust is certain parties who believe another one and when they are doing transaction, they do it based on beliefs, however, someone who is trusted will fulfill all his tasks well and complies with what other party is expecting (Parastanti, Kumadji, \& Hidayat, 2014).

\section{Decision to buy/purchase}

According to (Kotler and Keller, 2008 page 241), there are some steps to be done by the customers to decide on purchasing the product. Those steps are as the following (1) Problem Identification, (2) Information Searching. (3) Alternatives evaluation, (4) Decision to purchase, and (5) Behaviour after purchasing. These five steps have represented a general process that is driving the consumers to recognize the product to do purchase evaluation. This process is a guideline to study how the consumers has made a decision.

\section{Model of the Five Steps of the Process of Consumer Purchase}

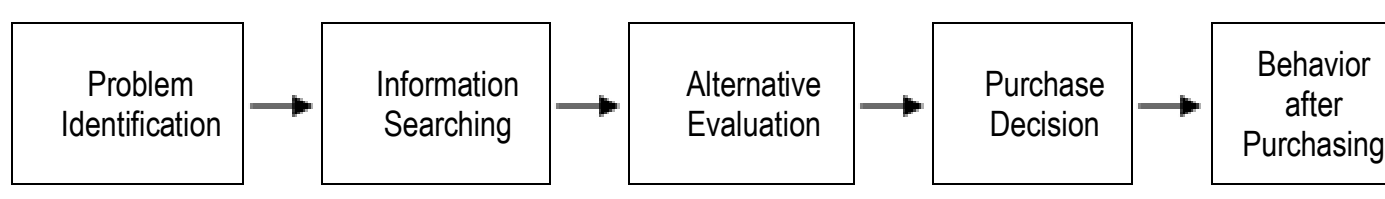

Figure 1

Model of the Five Steps of the Process of Consumers Purchase

\section{RESEARCH METHOD}

This research has applied descriptive quantitative method. Descriptive quantitative is to describe or to give a picture about the objects studied as the sample data or population as what they are supposed to be (Sugiyono, 2016: 29). This research has applied survey method using Regression analysis technique. Regression analysis technique is applied to obtain the information about the extent of which the relation between independent variable and dependent variable has happened (Hadi, 2014:1). The research has taken the samples of one population and has used questionnaires as the tools of data collection.

This research has applied primary data which is obtained by distribution the questionnaires to the students of STIE Binaniaga Bogor. The population of this research are the students of STIE Binaniaga Bogor which is 243 customers. In order to define total samples, it has applied Slovin equation, which is looseness of inaccuracy (e2) of $5 \%$ resulting 151 customers.

Validity and reliability test have to been done to figure out to what extent the instrument of this research is relied on. Classiical Assumpton Test is applied to get the value of the test which is not biased and efficiency of multiple linear equation model. Classical assumption test of this research is consisting of normality test, multicollinearity test, heteroscedasticity test.

Analysis Technique of this research has applied multiple regression analysis. Basically, multiple linear regression analysis is applied to indicate the effect of more than two variables. In this research, multiple regression analysis is applied to measure the extent of which the effect of independent variable and dependent variable has happened.

Adri Wihananto. The effect of price, comfort and trust upon the decision to buy at the online shop. (Case study on the students at Economic College of Binaniaga) 


\section{RESULT AND DESCRIPTION}

As described on the definition of variable operational in this research, Price $\left(X_{1}\right)$, Comfort $\left(\mathrm{X}_{2}\right)$, Trust $\left(\mathrm{X}_{3}\right)$, and Purchase Decision $(\mathrm{Y})$ which are indicated as the following:

\section{Validity Test}

Validity test has to be done in order to find out the validity level of an instrument (questionnaire) being applied in data collection which it is obtained by correlating each score of response variable with the total score of each variable, then the correlation result will be compared with critical value at sig.value of 0.05 .

Table 1.

Price Result of Validity Test

\begin{tabular}{|c|c|c|c|c|}
\hline No & Prie & rcount & rtable & Description \\
\hline 1 & Statement 1 & 0.612 & 0.312 & Valid \\
\hline 2 & Statemen 2 & 0.721 & 0.312 & Valid \\
\hline 3 & Statement 3 & 0.695 & 0.312 & Valid \\
\hline 4 & Statement 4 & 0.653 & 0.312 & Valid \\
\hline 5 & Statement 5 & 0.778 & 0.312 & Valid \\
\hline 6 & Statement 6 & 0.606 & 0.312 & Valid \\
\hline
\end{tabular}

Resource : data processed

Based on the result on the table above, it is concluded that each question of independent variable $X_{1}$ is valid because $r_{c o u n t}$ value $>r_{\text {table. }}$

Table 2.

Comfort Validity Test

\begin{tabular}{|c|l|c|c|c|}
\hline No & Comfort & rcount & rtabel & Description \\
\hline 1 & Statement 1 & 0.623 & 0.312 & Valid \\
\hline 2 & Statement 2 & 0.654 & 0.312 & Valid \\
\hline 3 & Statement 3 & 0.615 & 0.312 & Valid \\
\hline 4 & Statement 4 & 0.696 & 0.312 & Valid \\
\hline 5 & Statement 5 & 0.712 & 0.312 & Valid \\
\hline 6 & Statement 6 & 0.621 & 0.312 & Valid \\
\hline 7 & Statement 7 & 0.635 & 0.312 & Valid \\
\hline 8 & Statement 8 & 0.695 & 0.312 & Valid \\
\hline 9 & Statement 9 & 0.752 & 0.312 & Valid \\
\hline 10 & Statement 10 & 0.724 & 0.312 & Valid \\
\hline
\end{tabular}

Resource: Data processed

Based on the result on the table above, it is concluded that each question of independent variable $X_{2}$ is valid because $r_{\text {count }}>r_{\text {table. }}$

Table 3.

Trust Validity Test Result

\begin{tabular}{|c|l|c|c|c|}
\hline No & Trust & $r_{\text {count }}$ & rtable & Description \\
\hline 1 & Statement 1 & 0.635 & 0.312 & Valid \\
\hline 2 & Statement 2 & 0.626 & 0.312 & Valid \\
\hline
\end{tabular}

Adri Wihananto. The effect of price, comfort and trust upon the decision to buy at the online shop.

(Case study on the students at Economic College of Binaniaga)

Page : 4 


\begin{tabular}{|c|l|c|c|c|}
\hline No & Trust & $r_{\text {count }}$ & $r_{\text {table }}$ & Description \\
\hline 3 & Statement 3 & 0.682 & 0.312 & Valid \\
\hline 4 & Statement 4 & 0.625 & 0.312 & Valid \\
\hline 5 & Statement 5 & 0.722 & 0.312 & Valid \\
\hline 6 & Statement 6 & 0.653 & 0.312 & Valid \\
\hline 7 & Statement 7 & 0.718 & 0.312 & Valid \\
\hline 8 & Statement 8 & 0.614 & 0.312 & Valid \\
\hline
\end{tabular}

Resource: Data processed

Based on the result on the table above, it is concluded that each question of independent variable $X_{3}$ is valid due to $r_{\text {count }}>$ rtable.

Table 4.

Decision to buy online validity test result

\begin{tabular}{|c|l|c|c|c|}
\hline No & $\begin{array}{c}\text { Decision to } \\
\text { buy } \\
\text { Online }\end{array}$ & $r_{\text {count }}$ & $r_{\text {table }}$ & Description \\
\hline 1 & Statement 1 & 0.558 & 0.312 & Valid \\
\hline 2 & Statement 2 & 0.620 & 0.312 & Valid \\
\hline 3 & Statement 3 & 0.659 & 0.312 & Valid \\
\hline 4 & Statement 4 & 0.729 & 0.312 & Valid \\
\hline 5 & Statement 5 & 0.577 & 0.312 & Valid \\
\hline 6 & Statement 6 & 0.580 & 0.312 & Valid \\
\hline 7 & Statement 7 & 0.649 & 0.312 & Valid \\
\hline 8 & Statement 8 & 0.568 & 0.312 & Valid \\
\hline 9 & Statement 9 & 0.670 & 0.312 & Valid \\
\hline 10 & Statement 10 & 0.565 & 0.312 & Valid \\
\hline
\end{tabular}

Resource: Data processed

Based on the result on the table above, it is concluded that each question of dependent variable $Y$ is valid, due to $r_{\text {count }}>r_{\text {table. }}$.

\section{Reliability Test}

Reliability Test has to be done in order to figure out the consistence of respondent's response from time to time that is obtained by counting alpha coefficient using alpha cronbach's methode. If the result of $\alpha$ is $>0.06$, the related instrument will be high reliability. The following table is the result of reliability test of each variable:

Table 5.

Reliability Statistic

Reliability Statistic

\begin{tabular}{|l|r|l|}
\hline Variable & Critical Value & Conclusion \\
\hline Price & 0.758 & Reliable \\
\hline Comfort & 0.864 & Reliable \\
\hline Trust & 0.810 & Reliable \\
\hline Decision to buy online & 0.814 & Reliable \\
\hline
\end{tabular}

Adri Wihananto. The effect of price, comfort and trust upon the decision to buy at the online shop. (Case study on the students at Economic College of Binaniaga) 
Based on the value of alpha Cronbach above indicating that Price $\left(X_{1}\right)$ variable after being counted is 0.758 , Comfort $\left(X_{2}\right)$ variable is 0.864 , Trust $\left(X_{3}\right)$ variable is 0.810 and Decision to buy $(Y)$ variable is 0.814 , therefore it is indicated alpha value is bigger than critical value which is 0.6 . So that it can be concluded that measuring instrument which is questionnaires are reliable. So that, the questionnaires can be applied for further analysis.

\section{Hypotheses Test}

\section{Result of Multiple Linear Regression Analysis}

Referring to the result of data processed using program SPSS 20.00 for windows, it has obtained the equation of the following multiple linear regression:

Table 6.

Result of Analysis of Multiple Linear Regression

\begin{tabular}{|c|c|c|c|c|c|c|}
\hline & \multirow{2}{*}{ Mode } & \multicolumn{2}{|c|}{$\begin{array}{c}\text { Unstandardized } \\
\text { Coefficients }\end{array}$} & \multirow{2}{*}{$\begin{array}{c}\text { Standardized } \\
\text { Coefficients } \\
\text { Beta }\end{array}$} & \multirow{2}{*}{$t$} & \multirow{2}{*}{ Sig. } \\
\hline & & B & $\begin{array}{l}\text { Std. } \\
\text { Error }\end{array}$ & & & \\
\hline \multirow[t]{4}{*}{1} & (Constant) & 14.764 & 2.643 & & 5.585 & .000 \\
\hline & $\mathrm{X} 1$ & .379 & .083 & .319 & 4.552 & .000 \\
\hline & $\mathrm{X} 2$ & .315 & .070 & .360 & 4.480 & .000 \\
\hline & X3 & .178 & .082 & .156 & 2.165 & .032 \\
\hline
\end{tabular}

a Dependent Variable: $Y$

Referring to the result above, it has obtained the following multiple linear regression equation:

$Y=14.764+0.379 X_{1}+0.315 X_{2}+0.178 \times 3+e$

Interpretation of the above regression model are as the following:

1. Constant $=14.764$ indicating that the value of decision to buy online variable is affected by Price $\left(X_{1}\right)$ variable, Comfort $\left(X_{2}\right)$, Trust $\left(X_{3}\right)$ or independent variables $=0$, resulting the value of decision to buy on line variable of 14.764 .

2. The value of Price coefficient of 0.379 indicating that if price variable is increased according to the quality given will cause the increasing of decision to buy on line of 0.379 with the assumption other variables are constant.

3. The value of comfort coefficient of 0.315 indicating that if comfort variable is increased, it will cause the increasing of decision to buy online of 0.315 with the assumption that other variables are constant.

4. The value of trust coefficient of 0.178 indicating that if trust variable is increased, it will cause the increasing of decision to buy online of 0.178 , with the assumption other variables are constant.

Adri Wihananto. The effect of price, comfort and trust upon the decision to buy at the online shop.

(Case study on the students at Economic College of Binaniaga)

Page : 6 


\section{Determinant Coefficient}

Table 7

Determinant Coefficient

\begin{tabular}{l} 
Model Summary \\
\begin{tabular}{|l|c|r|l||c|}
\hline & & & & Std. Error \\
\hline Mode & & & Adjusted & of the \\
\hline $\mathrm{I}$ & $\mathrm{R}$ & R Square & R Square & Estimate \\
\hline 1 & $.675(\mathrm{a})$ & .455 & .444 & 2.211 \\
\hline
\end{tabular} \\
\hline
\end{tabular}

The value of correlation coefficient $(\mathrm{R})$ indicating close correlation between independent variables and dependent variable, the value of correlation coefficient is 0.455 . This value has shown that the correlation of price, comfort and trust variables with decision to buy online variable is strong which is $45.5 \%$.

\section{Hypotheses Proof}

\section{Test of Individual Parameter Significance (T test)}

Hypotheses proof has applied t test (partial test), to figure out whether quality of the service and price have affected the customer satisfaction. Herebelow is the output of spss t test:

Table 8.

Coefficients(a)

\begin{tabular}{|c|c|c|c|c|c|}
\hline \multirow[t]{2}{*}{ Model } & \multicolumn{2}{|c|}{$\begin{array}{c}\text { Unstandardized } \\
\text { Coefficients }\end{array}$} & $\begin{array}{c}\text { Standardized } \\
\text { Coefficients }\end{array}$ & \multirow[t]{2}{*}{$t$} & \multirow[t]{2}{*}{ Sig. } \\
\hline & $B$ & Std. Error & Beta & & \\
\hline (Constant) & 14.764 & 2.643 & & 5.585 & .000 \\
\hline$X 1$ & .379 & .083 & .319 & 4.552 & .000 \\
\hline$x 2$ & .315 & .070 & .360 & 4.480 & .000 \\
\hline$x 3$ & .178 & .082 & .156 & 2.165 & .032 \\
\hline
\end{tabular}

a Dependent Variable: $y$

Based on the table above, $t$ test result can be described as the following:

1. Price variable indicates tcount value of 4.552 , but table of Probability of $5 \%$ is 1.980 . Due to $t_{\text {count }}>t_{\text {table }}(4.552>1.980)$ and sig.value of $0.000<5 \%(0.05)$, it has shown that statistically price variable has affected significantly the variable of decision to buy online. Therefore, the hypothesis of this research is accepted.

2. Comfort variable indicates tcount value of 4.480 , and table at probability $5 \%$ is 1.980 . Therefore, due to tcount $>$ table $(4.480>1.980)$ and sig.value of $0.000<5 \%(0.05)$, so that it has described that statistically comfort variable has affected significantly the decision to buy online. Nevertheless this hypothesis of the research is accepted.

3. Trust variable indicates tcount of 2.160 , and table at the probability $5 \%$ is 1.980 . Since $t_{\text {count }}>t_{\text {table }}(2.160>1.980)$ and sig.value of $0.000<5 \%(0.05)$, therefore statistically trust variable has affected significantly the decision to buy online. Nevertheless, this hypothesis of the research is accepted.

Adri Wihananto. The effect of price, comfort and trust upon the decision to buy at the online shop. (Case study on the students at Economic College of Binaniaga) 


\section{Significance Test simultaneously (F test)}

Hypotheses proven has used f-test (simulant test) to figure out whether price, comfort and trust simultaneously have affected the decision to buy online. The following table is the output of spss $f$ test:

Table 9.

$\operatorname{ANOVA}(b)$

\begin{tabular}{|rl|r|r|r|r|l|}
\hline \multicolumn{1}{|l|}{ Model } & & $\begin{array}{r}\text { Sum of } \\
\text { Squares }\end{array}$ & df & Mean Square & F & Sig. \\
\hline 1 & Regression & 600.176 & 3 & 200.059 & 40.938 & $.000(\mathrm{a})$ \\
& Residual & 718.367 & 147 & 4.887 & & \\
& Total & 1318.543 & 150 & & & \\
\hline
\end{tabular}

a Predictors: (Constant), X3, X1, X2

b Dependent Variable: $y$

Referring to the table above, it has explained that $F_{\text {count }}$ of this model is 40.938 , but $F_{\text {table }}$ df: $\alpha,(k-1),(n-k)=0.05,(2-1),(151-3)$ which is 4.60 . Since $F_{\text {count }}>F_{\text {table }}(40.938>$ $4.60)$ and sig.value of $0.000<5 \%(0.05)$, it has shown that statistically variables of price, comfort and trust simultaneously have affected the decision to buy online. Nevertheless, the hypothesis of this research is accepted.

\section{CONCLUSION AND SUGGESTIONS} following:

Based on the result and description of this research, it can be concluded as the

1. Price variable has significantly affected the decision to buy online. It has indicated tcount of 4.552 , and table at the probability $5 \%$ is 1.980 . Since $t_{\text {count }}>t_{\text {table }}(4.552>1.980)$ and sig.value of $0.000<5 \%(0.05)$, it has explained that partially price has affected significantly the decision to buy online.

2. Comfort variable significantly has affected the decision to buy online. It has been indicated by tcount of 4.480 , and table at the probability $5 \%$ is 1.980 . Since $t_{\text {count }}>t_{\text {table }}$ $(4.480>1.980)$ and sig.value of $0.000<5 \%(0.05)$, it has explained that partially comfort has affected significantly the decision to buy online.

3. Trust variable has significantly affected the decision to buy online. It has been indicated by $t_{\text {count }}$ of 2.165 , and table at the probability $5 \%$ is 1.980 . Since $t_{\text {count }}>t_{\text {table }}$ $(2.165>1.980)$ and sig.value of $0.000<5 \%(0.05)$, it has explained that partially trust has affected significantly the decision to buy online.

4. Price, comfort and trust have affected the decision to buy online. It has been indicated by $F_{\text {count }}$ of 71.270 , and $F_{\text {table }}$ df: $\alpha,(k-1),(n-k)=0.05,(2-1),(146-3)$ which is 4.60 . Since $F_{\text {count }}>F_{\text {table }}(71.270>4.6)$ and sig.value of $0.000<5 \%(0.05)$, it has explained that statistically price, comfort and trust variable simultaneously have affected significantly the decision to buy online. It means that price, comfort and trust positively can increase the decision to buy online. following:

However, some suggestions are offered due to the result of the research as the

1. For further researchers. Further researchers are suggested to include other independent variables that have not been studied yet in this research, such as brand

Adri Wihananto. The effect of price, comfort and trust upon the decision to buy at the online shop.

(Case study on the students at Economic College of Binaniaga)

Page : 8 
image variable and brand trust variable. Other things that could be done by them are to perform other objects of the research. The research should have to be done at a different place since each business unit has different problem and will provide different result of analysis.

2. It is suggested that the party that has been dealing with online business is expected to provide clear, complete, and accurate information about procedure to order the product and to do the payment, procedure about delivery and return or change the product. So that, it will make consumer trust and believe the seller refers to the price perception which is having positive impact against the decision to buy.

\section{REFERENCES}

Balakrishnan, Dahnil \& Yi. 2014. The Impact of Social Media Marketing Medium Toward Purchase Intention and Brand Loyalty Among Generation Y. Procedia-Social and Behavioral Sciences, pp $177-185$.

Kotler dan Keller. (2009), Marketing Manajemen, jilid 1.Edisi ke-13. Jakarta: Erlangga.

Kotler, P. dan Gary Armstrong. (2008). Prinsip-prinsip Pemasaran.Edisi Ke-12 Jilid 1.Jakarta : Erlangga.

Mahkota, A. P., Suyadi, I., Riyadi. (2014). Pengaruh kepercayaan dan kenyamanan terhadap keputusan pembelian online (Studi pada Pelanggan Website Ride Inc). Jurnal Administrasi Bisnis Vol. 8 No. 2.

Morissan. 2010. Periklanan Komunikasi Pemasaran Terpadu. Jakarta: Kencana Prenanda Media Group.

Palvia, P. 2009. The role of trust in e-commerce relational exchange: A unified model. Information \& Management, 213-220.

Parastanti, G. P., Kumadji, S., \& Hidayat, K. 2014. Pengaruh Prior Online Purchase Experience Terhadap Trust dan Online Repurchase Intention. Jurnal Administrasi Bisnis (JAB).

Sarkar, A. 2011. Impact of Utilitarian and Hedonic Shopping Values on Individual's Perceived Benefits and Risks in Online Shopping . International Management Review

Sunyoto, Danang. 2013. Teori Kuesioner dan Analisis Data untuk Pemasaran dan Prilaku Konsumen. Yogyakarta: Graha IImu.

Adri Wihananto. The effect of price, comfort and trust upon the decision to buy at the online shop. (Case study on the students at Economic College of Binaniaga) 
The Management Journal of BINANIAGA Vol. 05, No. 01, June 2020

p-ISSN: 2527 - 4317, e-ISSN: $2580-149 x$

$6^{\text {th }}$ Accreditation Rating: April 04, 2019 - April 03, 2024

This page intentionally be emptied.

Adri Wihananto. The effect of price, comfort and trust upon the decision to buy at the online shop. (Case study on the students at Economic College of Binaniaga)

Page : 10 